\title{
Nursing the Fatherland? Hohenzollern State Building and the Hidden Transcript of Political Resistance in Hanoverian Female Charity during the Second German Empire
}

\author{
Jasper M. Heinzen
}

$\mathrm{I}$

N summer 1866 the Austro-Prussian struggle for supremacy in Germany erupted into open conflict. King Georg V of Hanover sided with other governments loyal to the German Confederation against Prussia, but after initially defeating Prussian forces at Langensalza, he was forced to capitulate. ${ }^{1}$ Two days after the battle, on June 29, 1866, the widow of the Hanoverian general Sir Georg Julius von Hartmann told her daughter in no uncertain terms how she felt about the Prussian government and its allies. In her opinion they were nothing more than "robber states" that cloaked their disregard for the Ten Commandments in sanctimonious public displays of piety. "These Protestant Jesuits," she continued, "offend me more than the Catholic ones. You know that I am German with all my heart and love my Germany, but I cannot consider them genuine Germans anymore because they only want to make Germany Prussian." 2

Like many older members of the Hanoverian haute bourgeoisie and nobility, this veteran of the Prussian and French occupations of the Guelph electorate at the beginning of the nineteenth century espoused a federal vision of German unity that saw in Prussia's territorial expansion a mortal threat to the authentic character

The author wishes to thank the anonymous reviewers of Central European History, Brendan Simms, Johannes Wischmeyer, and Frauke Kersten-Schmunk for their comments on earlier drafts of this article, and gratefully acknowledges funding from the British Arts and Humanities Research Council, the Sir John H. Plumb Charitable Trust of Cambridge, the Institute of European History in Mainz, and the Deutscher Akademischer Austausch Dienst (DAAD), whose support was instrumental in the completion of this paper.

${ }^{1}$ For a more detailed overview, see contributions in Rainer Sabelleck, ed., Hannovers Übergang vom Königreich zur preußischen Provinz (Hannover: Hahn, 1995); Heide Barmeyer, Hannovers Eingliederung in den preußischen Staat: Annexion und administrative Integration 1866-1868 (Hildesheim: Lax, 1983); Ernst Pitz, "Deutschland und Hannover im Jahre 1866," Niedersächsisches Jahrbuch für Landesgeschichte 38 (1966): 86-158.

${ }^{2}$ Marianne von Hartmann to her daughter Marie, June 29, 1866, Niedersächsisches Hauptstaatsarchiv Hannover (hereafter NHStAH), Hann. 91 v. Hartmann, Nr. 5, fol. 216. Emphasis in the original. 
of the nation. These concerns hardly dissipated when the Hohenzollerns officially annexed Hanover three months later. ${ }^{3}$ For a Guelph loyalist such as Marianne von Hartmann the regime change was an emotional shock, and her English son-inlaw was only half joking when he wished the old lady in 1868 "May you live yet to see George V in Hannover. For Guillaume and Bismarck I shall not wish Evil / But I must say I think they will go to the Devil. Three Hurrahs for the fight against dastardly Night." " By itself Hartmann's anti-Prussian bias would have been unremarkable were it not for the fact that she occupied a leading position on the steering committee of one of Hanover's premier charities, the Henriettenstift. She and her peers found themselves in the uncomfortable position of having to reconcile their private hostility toward Bismarck and pragmatic cooperation with the new regime to continue their work of benevolence.

Political concerns were therefore never far from the surface of Hanoverian charity. In his groundbreaking work The Transformation of the Public Sphere of 1962, Jürgen Habermas painted the liberal public sphere, which emerged in western societies during the Enlightenment, as inherently exclusionary. For public - political-life to exist, it had to be complemented by a private realm of female domesticity within the bourgeois family. ${ }^{5}$ Women's and gender historians have criticized the public/private dichotomy for its gender bias. Substantial research in the intervening fifty years has succeeded in reappraising women's place in the body politic and overcoming the "built-in antithesis between the two fields of history, histories of nations and histories of gender."

\footnotetext{
${ }^{3}$ Since both the province and the provincial capital shared the same name in the nineteenth century, this article uses dissimilar spelling to distinguish them ("Hanover" and "Hannover," respectively). Pitz, "Deutschland und Hannover," 147.

${ }^{4}$ Lewis Gordon to Marianne von Hartmann, March 20, 1868, NHStAH, Hann. 91 v. Hartmann, Nr. 12, fol. 131. English text and emphasis in the original.

${ }^{5}$ Jürgen Habermas, Strukturwandel der Öffentlichkeit. Untersuchungen zu einer Kategorie der bürgerlichen Gesellschaft, 2nd ed. (Neuwied am Rhein: Luchterhand, 1965), 55-68.

${ }^{6}$ Ida Blom, "Gender and Nation in International Comparison," in Gendered Nations: Nationalisms and Gender Order in the Long Nineteenth Century, ed. Ida Blom, Karen Hagemann, and Catherine Hall (Oxford and New York: Berg, 2000), 3. The literature on the subject is vast. See Lynn Abrams and Elizabeth Harvey, "Introduction: Gender and Gender Relations in German History," in Gender Relations in German History: Power, Agency, and Experience from the Sixteenth to the Twentieth Century, ed. Lynn Abrams and Elizabeth Harvey (London: University College London Press, 1996), 16-27; Joan W. Scott, Gender and the Politics of History (New York: Columbia University Press, 1988), esp. 26, 48; Angelika Schaser, “The Challenge of Gender: National Historiography, Nationalism, and National Identities," in Gendering Modern German History, ed. Karen Hagemann and Jean H. Quataert (New York and Oxford: Berghahn, 2008), 39-62; Belinda Davis, "Reconsidering Habermas, Gender, and the Public Sphere: The Case of Wilhelmine Germany," in Society, Culture, and the State in Germany, 1870-1930, ed. Geoff Eley (Ann Arbor, MI: University of Michigan Press, 1996), 405; Nancy Reagin, Sweeping the German Nation: Domesticity and National Identity in Germany, 1870-1945 (Cambridge: Cambridge University Press, 2007); and Ute Planert, "Vater Staat und Mutter Germania. Zur Politisierung des weiblichen Geschlechts im 19. und 20. Jahrhundert," in Nation, Politik und Geschlecht. Frauenbewegungen und Nationalismus in der Moderne, ed. Ute Planert (Frankfurt am Main and New York: Campus, 2000), 15-65.
} 
Women's history has made especially insightful contributions to nationalism studies by examining the correlation between female charity and patriotism. While the public face of the state was ostensibly that of a masculine warmaking machine, the language of humanitarian aid consolidated the image of a complementary "caring" and, thanks to the growing medicalization of society, "curing" state. ${ }^{7}$ Both constituted two sides of the same coin inasmuch as patriotic women's associations - the carriers of a "female public" —and Germany's dynastic establishment espoused common notions of service to the fatherland, making popular identification with the state all the more possible when war came in 1914.8

Jean H. Quataert makes a strong case for the contribution of women to the production of definitions of community membership through philanthropy and the often-overlooked place therein of dynastic rituals of patronage centered on the royal Landesmutter (mother of the people). On the other hand, the ties that linked patrons and beneficiaries undercut just as well as reinforced the process of state building. The grant of royal approval bestowed legitimacy on local charity, but in a circular fashion the symbolic capital of the court rose and fell with the public perception of the latter's moral character. Baron Stockmar, Queen Victoria of Britain's German-born adviser, tellingly counseled his mistress that a reputation for "practical morality" was "the indispensable necessity" to the welfare of both sovereign and the people. ${ }^{9}$ The Hohenzollerns struggled to implement this dimension of statecraft because influential critics such as Marianne von Hartmann saw their morals trailing far behind their hunger for power. As a result, the Prussian monarchy lost moral authority to its vanquished rivals, the Guelphs, whose continuing involvement in philanthropy nurtured alternative political loyalties.

The aim of the present article is to show how Hanoverian female charities negotiated these competing dynastic identities against the larger backdrop of religious conflict and the "woman question" in the Kaiserreich. This analytical approach promises a richer understanding of the spiritual "coding" of women's contribution to state building. The case of confessional nursing throws into relief formative dynamics of competition that pitted Catholic, Lutheran, and

${ }^{7}$ Jean H. Quataert, "Mobilizing Philanthropy in the Service of War: The Female Rituals of Care in the New Germany, 1871-1914," in Anticipating Total War: The German and American Experiences, 1871-1914, ed. Manfred F. Boehmeke, Roger Chickering, and Stig Förster (Cambridge and New York: Cambridge University Press, 1999), 221. See also Jean H. Quataert, Staging Philanthropy: Patriotic Women and the National Imagination in Dynastic Germany, 1813-1916 (Ann Arbor, MI: University of Michigan Press, 2001).

${ }^{8}$ Quataert, "Mobilizing Philanthropy,” 230-31; Andrea Süchting-Hänger, “"Gleichgroße mut'ge Helferinnen' in der weiblichen Gegenwelt. Der Vaterländische Frauenverein und die Politisierung konservativer Frauen 1890-1914," in Nation, Politik und Geschlecht, ed. Planert, 131-46.

${ }^{9}$ Baron Stockmar cited in Frank Prochaska, Royal Bounty: The Making of a Welfare Monarchy (New Haven, CT, and London: Yale University Press, 1995), 76. 
nationalprotestantisch Red Cross motherhouses against each other in search of patronage. So far the implications of these separate religious worlds for the construction of an integrative sense of nationhood remain largely unexplored..$^{10}$ This is an important theme, however, because the proliferation of religious charity in the nineteenth century expanded women's participation in public life, even where, ironically, confessional nurses identified with traditional gender roles as nurturers. ${ }^{11}$

The central argument put forth here is that despite the gravity of political cleavages in Hanoverian charity, the new regime's quest for moral validation on the one hand and the diversification of public welfare services on the other worked to weld Guelph and Hohenzollern philanthropy together in defense of conservative social interests. In contradistinction to Quataert and Ute Daniel, who conclude that Hohenzollern attitudes toward civic philanthropy endeavored to bridge the confessional Christian divide, this article contends that the carefully calibrated perpetuation of competition deserves more attention. ${ }^{12}$ Adjusting the focus to the regional level is highly conducive to explaining conflicts as well as modes of accommodation that shaped "social relations on the ground," as one historian of the Culture War recently advised. ${ }^{13}$ A comparison of four Hanoverian nursing organizations-the Frederica Association, the Sisters of Charity in Hildesheim, the Henriettenstift, and the Clementinenhaus-will therefore illuminate how the political reorientation of female patriotism-cum-piety in an initially non-Prussian context was processed at the grassroots. Protestant perspectives claim pride of place because they showcase evocatively the contestation

\footnotetext{
${ }^{10}$ Quite rightly Helmut W. Smith points out in his review of Quataert's Staging Philanthrophy, "The separate, if sometime cooperating, worlds of Catholic and Jewish philanthropy suggest that the confessional, indeed Protestant, coding of the philanthropic work of the women's organizations was stronger than Quataert supposes." The Jewish presence in Hanoverian nursing was negligible, but the present article suggests that even the Protestant "coding" was far from unambiguous. Helmut W. Smith, "Book Review of Staging Philanthropy," American Historical Review 107 (2002): 1651.

${ }^{11}$ On the challenge of the expansion of religious charity to liberal antifeminism, see Michael B. Gross, The War against Catholicism: Liberalism and the Anti-Catholic Imagination in Nineteenth-Century Germany (Ann Arbor, MI: University of Michigan Press, 2004), esp.184-87. Geoff Eley, “'An Embarrassment to the Family, to the Public, and to the State': Liberalism and the Rights of Women, 1860-1914," in Wilhelmine Germany and Edwardian Britain: Essays on Cultural Affinity, ed. Dominik Geppert and Robert Gerwarth (Oxford: Oxford University Press, 2008), 143-71.

${ }^{12}$ Quataert, Staging Philanthropy, 130. Ute Daniel, "Die Vaterländischen Frauenvereine in Westfalen," Westfälische Forschungen 39 (1989): 171. My claim meshes with Helmut W. Smith's central argument that the persistence of religious conflict was "an integral part of the complexities of the jagged, irregular process by which German lands became a modern, secular, increasingly integrated, nationally cohesive polity." Helmut W. Smith, German Nationalism and Religious Conflict: Culture, Ideology, Politics, 1870-1914 (Princeton, NJ: Princeton University Press, 1995), 79. Cf. Wolfgang Altgeld, Katholizismus, Protestantismus, Judentum. Über religiös begründete Gegensätze und nationalreligiöse Ideen in der Geschichte des deutschen Nationalismus (Mainz: Matthias-Grünewald Verlag, 1992).

${ }^{13}$ Oliver Zimmer, "Beneath the 'Culture War': Corpus Christi Processions and Mutual Accommodation in the Second German Empire," Journal of Modern History 82 (2010): 298.
} 
of kleindeutsch identity below the surface of public discourse. The first part of the discussion outlines a "hidden transcript" of silent dissent that pious Lutherans adopted to dissociate themselves from the ruthlessness of Prussian raison d'état. The remainder of the article engages with the social space of benevolence, domains of cooperation with the Hohenzollern regime, and dynamics of competition between charities that pushed forward their uneven but nevertheless steady nationalization before 1914.

The early nineteenth-century was a period of spiritual renovation (Erweckung) in German Protestantism. In answer to the social problems caused by industrialization, pioneers of the Inner Mission such as the Hamburg pastor Johann Hinrich Wichern aimed to re-Christianize society through good works among the lower classes and an overall revalorization of moral values. Susceptibility to the religious revival proved greatest among women. ${ }^{14}$ The first impulse for their participation in the practical implementation of the Erweckung emanated from the daughter of a Hamburg senator, Amalie Sieveking, who founded the "Female Association for the Care of the Poor and Sick" in 1832.15 She soon found admirers in the neighboring kingdom of Hanover where urban growth and incipient industrial development fueled pauperism. The population of the capital city, for instance, enlarged from 25,000 to 100,000 within the relatively short time span of only forty years (1830-1873), overtaxing the state's capacity to deal with the pool of indigents. ${ }^{16}$ Modeling themselves on Sieveking and the Inner Mission, Hannover's elite women set up the Frederica Association in 1840 to offer families in need spiritual support, job referrals, clothes, and food. Tasks diversified as the king, Ernst August, granted them free use of an estate to set up a hospital, kindergarten, and training school for nurses. Other

\footnotetext{
${ }^{14}$ Hugh McLeod, "Weibliche Frömmigkeit - männlicher Unglaube? Religion und Kirchen im bürgerlichen 19. Jahrhundert," in Bürgerinnen und Bürger. Geschlechterverhältnisse im 19. Jahrhundert, ed. Ute Frevert (Göttingen: Vandenhoeck \& Ruprecht, 1988), 134-56. Lucian Hölscher, "Möglichkeiten und Grenzen der statistischen Erfassung kirchlicher Bindungen," in Seelsorge und Diakonie in Berlin. Beiträge zum Verhältnis von Kirche und Großstadt im 19. und beginnenden 20. Jahrhundert, ed. Kaspar Elm and Hans-Dietrich Loock (Berlin: de Gruyter, 1990), 39-59.

${ }^{15}$ Ursula Baumann, Protestantismus und Frauenemanzipation in Deutschland. 1850 bis 1920 (Frankfurt and New York: Campus, 1992), 38-43. See also Lucian Hölscher, "WWibliche Religiosität'? Der Einfluß von Religion und Kirche auf die Religiosität von Frauen im 19. Jahrhundert," in Erziehung der Menschen-Geschlechter. Studien zur Religion, Sozialisation und Bildung in Europa seit der Aufklärung, ed. Margret Kraul and Christoph Lüth (Weinheim: Deutscher Studien Verlag, 1996), 50.

${ }^{16}$ Christiane Schröder, "Eine neue Heimat im Mutterhaus. Protestantische Schwesternschaften," in Außer Haus. Frauengeschichte in Hannover, ed. Christiane Schröder and Monika Sonneck (Hannover: Reichold, 1994), 30. Prior to the termination of the Anglo-Hanoverian Personal Union in 1837, private charity in Hannover consisted of the aristocratic Childbed Association for poor expectant mothers and the Association of the Day-Care School of the Inner City of Hannover. Nancy R. Reagin, A German Women's Movement: Class and Gender in Hanover, 1880-1933 (Chapel Hill, NC, and London: University of North Carolina Press, 1995), 30-31.
} 
benefactors in subsequent decades included patients grateful for the excellent service provided by the "Sisters of Frederica," as the nurses employed by the Frederica Association came to be known. ${ }^{17}$

Like its Protestant counterpart, Catholicism went through a phase of spiritual regeneration after the dramatic decline of ecclesiastical authority during the French Revolution. Religious orders and monasteries gained a new lease on life, as did campaigns of popular missions (Volksmissionen) and folkloric expressions of piety such as pilgrimages and religious festivals. ${ }^{18}$ The Sisters of Charity traced their origins to St. Vincent de Paul's efforts in the seventeenth century to help the poor and sick, yet the Catholic revival of the nineteenth century was needed to extend their sphere of operation from Prussia to Hildesheim in the 1850s. ${ }^{19}$ Initially, the Hanoverian government refused the congregation legal recognition on the grounds that the sisters were Prussian subjects; however, the latter quickly made a name for themselves both because of their proficiency and confessional tolerance in the treatment of patients. ${ }^{20}$ This set the Hanoverian case apart from other denominationally mixed societies such as Ireland where the compatibility of nurse and patient was pivotal. ${ }^{21}$

The underlying competitiveness of Catholic and Protestant charity was nevertheless noticeable, especially in the diaconal motherhouses that mushroomed on the fertile soil of the Inner Mission. Inspired by the work of the Fliedners at Kaiserswerth, who made no bones about their ambition to keep Catholic benevolence in check, Queen Marie of Hanover used a bequest from her late grandmother to found a Lutheran care-giving sisterhood patterned on the Sisters of

\footnotetext{
${ }^{17}$ Diakoniewerk Friederikenstift Hannover, Verbundenheit zum Erbe-Mut zum Neuen. Die Geschichte der Friederikenschwesternschaft in Hannover (Hannover: Friederikenstift, 2003), 8-13.

${ }^{18}$ Christopher Clark and Wolfram Kaiser, "Kulturkampf in Europa im 19. Jahrhundert," in Kulturkampf in Europa im 19. Jahrhundert, ed. Christopher Clark and Wolfram Kaiser (Leipzig: Leipziger Universitätsverlag, 2002), 16-21. Michael B. Gross, "The Catholic Missionary Crusade and the Protestant Revival in Nineteenth-Century Germany," in Protestants, Catholics, and Jews in Germany, 1800-1914, ed. Helmut Walser Smith (Oxford and New York: Berg, 2001), 245-66. David Blackbourn, Marpingen: Apparitions of the Virgin Mary in Bismarckian Germany (Oxford: Clarendon Press, 1993), 85-95. There is some debate concerning periodization, but agreement exists that the religious revival was in full swing by the 1850s. Cf. Jonathan Sperber, Popular Catholicism in Nineteenth-Century Germany (Princeton, NJ: Princeton University Press, 1984). Margaret Lavinia Anderson, "Piety and Politics: Recent Work on German Catholicism," Journal of Modern History 63 (1991): 681-90.

${ }^{19}$ Lieselotte Sterner, Die Kongregation der Barmherzigen Schwestern vom hl. Vinzenz von Paul in Hildesheim von 1852 bis zum Zweiten Vatikanischen Konzil. Untersuchung einer karitativen Ordensgemeinschaft vor dem Hintergrund der sozialen und politischen Entwicklung im 19. und 20. Jahrhundert (Hannover: Hahn, 1999), 37-43. Relinde Meiwes, "Katholische Frauenkongregationen und die Krankenpflege im 19. Jahrhundert," L'Homme 19 (2008): 53-54.

${ }^{20}$ Sterner, Kongregation der Barmherzigen Schwestern, 48-57. Traudel Weber-Reich, "Wir sind die Pionierinnen der Pflege." Krankenschwestern und ihre Pflegestätten im 19. Jahrhundert am Beispiel Göttingen (Bern and Göttingen: Huber, 2003), 53-65.

${ }^{21}$ Margaret H. Preston, Charitable Words: Women, Philanthropy, and the Language of Charity in Nineteenth-Century Dublin (Westport and London: Praeger Publishers, 2004), 4.
} 
Charity in 1860.22 The Henriettenstift, as it was called, deviated somewhat from the Kaiserswerth prototype because a matron with the title Oberin (reverend mother) was placed in charge, reinforcing the close resemblance of deaconesses and nuns. Orthodox Lutherans disliked the Catholic connotations of Diakonie, while East Frisian Calvinists mistrusted the pet project of an unloved Lutheran monarch. Due to the controversy surrounding the Henriettenstift, the convent still struggled when war found the kingdom in $1866 .^{23}$

While everybody lamented the sad aftermath of Langensalza, the wounded and dying who required medical attention were, a cynic might say, blessings in disguise for the Hanoverian deaconesses and the Catholic sisters from Hildesheim. Although the carnage left the nurses dispatched to the theater of war with mental scarring, their dedication to the work of benevolence during this "baptism of fire" made for positive publicity that the Henriettenstift, for one, desperately needed. In the long term, wartime service hitched their fate to the war-making capabilities of the national community and thus opened up complementary spaces for women in Prussia-Germany's masculine warrior culture. ${ }^{24}$ In 1866, however, these developments still were in their infancy. Of more immediate concern to the Hanoverian deaconesses and the Sisters of Frederica then were the humiliation and eventual removal of their royal patron.

Worries about the future and infuriation at the Prussian occupation force's treatment of Queen Marie at her palace in Herrenhausen and Marienburg Castle kept anti-Prussian resentments alive. As one of Queen Marie's confidantes and founding member of both the Frederica Association and the Henriettenstift, Marianne von Hartmann expressed outrage at the constant surveillance. That Bismarck may have had reason to be suspicious of the queen's skillful manipulation of public opinion defied her and her colleague's comprehension. ${ }^{25}$ Marie's image as a victim of persecution subsequently developed into a cornerstone of the two Guelph charities' identity and defined how they came to interact

\footnotetext{
${ }^{22}$ For a general history of the Kaiserswerth model, see Ruth Felgentreff, Das Diakoniewerk Kaiserswerth, 1836-1998 (Kaiserswerth: Heimat- und Bürgerverein Kaiserswerth, 1998). Ute Gause and Cordula Lissner, eds., Kosmos Diakonissenmutterhaus. Geschichte und Gedächtnis einer protestantischen Frauengemeinschaft (Leipzig: Evangelische Verlagsanstalt, 2005).

${ }^{23}$ Dieter Brosius, “"Allerhöchstihrer Majestät Lieblingsstiftung.” Königin Marie von Hannover und das Henriettenstift," in . . neue Wege, alte Ziele. 125 Jahre Henriettenstiftung Hannover, ed. Wolfgang Helbig (Hannover: Lutherhaus-Verlag, 1985), 131-36. Marie Ballauf, Herzogin Henriette von Württemberg und Königin Marie von Hannover (Hermannsburg: Missionsbuchhandlung, 1910), 1-46.

${ }^{24}$ Quataert, "Mobilizing Philanthropy," 226-31. Karen Hagemann, "Venus und Mars. Reflexionen zu einer Geschlechtergeschichte von Militär und Krieg," in Landsknechte, Soldatenfrauen und Nationalkrieger. Militär, Krieg und Geschlechterordnung im historischen Wandel, ed. Karen Hagemann and Ralf Pröve (Frankfurt am Main and New York: Campus, 1998), 13-50. For a more detailed account of the deaconesses' work at Langensalza, see Gerhard Uhlhorn, Die Arbeit der Diaconissen im letzten Kriege (Hannover: Meyer, 1867).

${ }^{25}$ Von Hartmann to her daughter Marie, May 27, 1867, NHStAH, Hann. 91 v. Hartmann, Nr. 5, fols. 226-28.
} 
with the "martyred" exiled royal dynasty. The in-house chronicle of the Henriettenstift, for one, noted about the changes after the annexation: "Our beloved queen withdrew to the Marienburg. The reverend mother visited her there and the queen took as usual a most hearty interest in the goings-on at the convent. On September 20 [1866], she visited her cherished convent for the last time [and] handed over a crucifix for safekeeping with the words, 'It is especially dear to me; look after it so that it will not fall into foreign hands." 26

This episode showcases how Guelph loyalists married verbal double entendre with sacral symbology to insert a powerful element of Prussophobia into the mission of Lutheran female charity. This particular response to the annexation supports the notion of the "hidden transcript" first developed by the historical anthropologist James C. Scott. He maintained that the self-perpetuating enactment of power relations between masters and subordinates invariably depended on the coexistence of two discourses-one hegemonic and public, the other polyvalent and hidden from the gaze of the powerful. The hidden transcript, then, was a "politics of disguise" and a "social space in which offstage dissent to the official transcript of power relations may be voiced." 27 Following the reversal of hidden and public transcripts in 1866, which entailed the metamorphosis of the Guelph dynastic cult into a counterculture, creative strategies of concealment and outward adaptation to Hohenzollern rule became the order of the day. The governing body of the deaconesses' convent was offended enough by Bismarck's war on the church to offer disaffected pastors, who rebelled against the revocation of ecclesiastical supervisory rights in primary schools, use of its facility for a wellattended protest conference in $1872 .{ }^{28}$ Open clashes nevertheless remained the exception.

The development of a coded language of ambiguity channeled resentment of the Hohenzollerns very effectively. At the basic level, this technique served as a mental buffer between the Prussian "public" and the Hanoverian "hidden" transcripts. The first test came soon enough with the introduction of mandatory prayers for King Wilhelm I of Prussia in the churches of the former Guelph kingdom in 1866. Gerhard Uhlhorn, the house chaplain of the deaconesses' convent at the time, could ill afford to defy the decree openly, yet he and the other members of the steering committee also felt no inclination to alienate their patrons, King Georg V and his wife, who adamantly refused to acknowledge the annexation. Uhlhorn navigated these shoals by praying for the well-being of

\footnotetext{
26 “Chronik des Henriettenstifts. 1885 geschrieben von I.M. der Königin eigenhändig” [contrary to the title, authorship of the chronicle has not been fully established], Archiv der Henriettenstiftung, fol. 4 .

${ }^{27}$ James C. Scott, Domination and the Arts of Resistance: Hidden Transcripts (New Haven, CT: Yale University Press, 1990), xi, 19.

${ }^{28}$ Wolfgang Rädisch, Die Evangelisch-lutherische Landeskirche Hannovers und der preußische Staat, 1866-1885 (Hildesheim: Lax, 1972), 111.
} 
the "lord of our house" in his religious services, thereby leaving it to the imagination of his listeners to figure out whom he meant. ${ }^{29}$ For Uhlhorn, at any rate, conformity to the rules of the public transcript paid off because he finished his stellar career as abbot of Loccum, chief theologian of the Hanoverian Lutheran church. $^{30}$

While Uhlhorn and his successor in the office of convent chaplain, Johannes Büttner, were proponents of balance, however, they did not hold back their contempt for hypernationalism when it threatened to overtake the spiritual goals of the Inner Mission. Nation-worship without regard for the divine fatherland encouraged excessive pride and hatred toward other peoples, and Uhlhorn berated super-patriots during the feverish days after the outbreak of the Franco-Prussian War in 1870. Nineteen years later Büttner put the following evocative question to Hanoverian deaconesses and Diakonie supporters in the convent's bimonthly journal Blätter aus dem Henriettenstift: "And should Jesus Christ not be entitled ... to demand the same [attention] where matters a thousand times more important than the earthly Volk and fatherland - the holy realm of God, the salvation from sin and death, and the conquest or loss of the heavenly fatherland - are concerned?" 31 At other times the absence of important news items underlined equally effectively the convent's emotional distance from the Hohenzollern regime for several decades after the annexation. Current events, with the exception of deaths in the family of their royal benefactors, found very little mention in the journal-even when these occasions were as momentous as the passing of two Kaisers in one year (1888).

Mental buffering and the immunization of Lutheran deaconesses against other secular attachments concomitantly depended on continued, tangible, and direct contact between the members of the two Lutheran charities and the Guelph exile court in Austria. Importantly, the former queen retained the right to approve and veto key appointments to the committee of the Henriettenstift. The long-serving matron Anna Forcke (1866-1898) herself insisted that only "good Hanoverians" be elected to positions of influence within the convent. The queen therefore had little to fear from dissenters. ${ }^{32}$ Marie could exercise her powers with confidence because Forcke and Büttner updated her about the internal affairs of the convent by way of regular letters and visits to Austria. ${ }^{33}$ Neither of the Stift's two leading representatives had any reason to

\footnotetext{
${ }^{29}$ Brosius, “'Allerhöchstihrer Majestät Lieblingsstiftung,”" 138.

${ }^{30}$ Even though Uhlhorn's son later claimed that the Guelphs always owned his heart, the ambitious clergyman's studied political neutrality in church affairs did not do him any credit in the eyes of the exiled dynasty. In 1869 he relinquished his position as chaplain at the Henriettenstift. Friedrich Uhlhorn, Gerhard Uhlhorn, Abt zu Loccum. Ein Lebensbild (Stuttgart: Gundert, 1903), 159.

${ }^{31}$ Uhlhorn, Gerhard Uhlhorn, 176; Blätter aus dem Henriettenstift 20, nos. 4-5 (1889): 14.

${ }^{32}$ Brosius, “"Allerhöchstihrer Majestät Lieblingsstiftung,"” 134.

${ }^{33}$ Ballauff, Herzogin Henriette von Württemberg, 60-61.
} 
take her trust for granted, though, because Hartmann officiated as her extended arm and personal envoy on the committee. Her responsibilities included the distribution of silver crosses (gold for the matron), which all deaconesses received as a personal gift from the queen to wear with their habits. ${ }^{34}$ Relying on the power of these sanctified Guelph objets de mémoire, the Sisters of Frederica, too, incorporated them into their quotidian lives as symbols of their professional status. To this day, all novices who have passed their nurse's exam are entitled to wear a "Frederica brooch" depicting the Rose of Luther with a capital letter "F" in the center below a representation of the crown of Hanover. ${ }^{35}$ Mementos of the deposed royal family were hence present in both charities' routine activities, and in some cases, deaconesses visited Queen Marie's palace at Gmunden or exchanged genial letters with her or her daughters. ${ }^{36}$

Of course, pleasantries alone could not buy the Hanoverian royal émigrés influence in the charities. Rather, they guessed correctly that the most effective strategy to cultivate sympathies among their former subjects and keep the hidden transcript alive was through displays of practical virtue. Queen Marie usually sent the Henriettenstift about 300 RM per annum, not counting Christmas gifts she and her daughters made by hand as well as irregular subsidies of higher value. On her death in 1907, she bequeathed 50,000 RM to the deaconesses. $^{37}$ Crown Prince Ernst August, who assumed the title duke of Cumberland and became the head of the family after King Georg V's passing in 1878, matched his mother's generosity by chipping in when the two Lutheran benevolent organizations needed money for new building projects. ${ }^{38}$

These donations came nowhere near to covering all expenses, but they had an undeniable psychological effect. ${ }^{39}$ In April 1891 the steering committee of the Hanoverian Children's Hospital complained to the German chancellor,

\footnotetext{
${ }^{34}$ Anna von Wangenheim to Marianne von Hartmann, Oct. 6, 1880, NHStAH, Hann. 91 v. Hartmann, Nr. 7, fols. 154-54v. Johannes Büttner, Das Henriettenstift und seine Arbeitsgebiete (Hannover: Wolff and Hohorst, 1885), 25.

${ }^{35}$ Diakoniewerk Friederikenstift Hannover, Verbundenheit zum Erbe, 35-36.

${ }^{36}$ Ballauff, Herzogin Henriette von Württemberg, 60. A good example of sustained contact between deaconesses and members of the royal house is Franziska von Hammerstein's correspondence with Princess Mary and Princess Friederike of Hanover. NHStAH, Dep. 52, IV, Nr. 297. Further letters from deaconesses can be found in NHStAH, Dep. 103 XXI, Nr. 1002-4.

${ }^{37}$ Johannes Schwerdtmann, Das Henriettenstift und seine Arbeitsgebiete (Hannover: Henriettenstift, 1910), 242.

${ }^{38}$ In 1894, for instance, the duke of Cumberland topped the Frederica Association's list of individual donors with a 3,000 RM contribution. Bericht des Frauen-Vereins für Armen- und Krankenpflege im Friederikenstift zu Hannover für das Jahr 1894 (Hannover: Friederikenstift, 1894), 4.

${ }^{39}$ For a sophisticated analysis of philanthropic gift exchange in nineteenth-century Germany from a sociological perspective, see Stephen Pielhoff, "Stifter und Anstifter. Vermittler zwischen 'Zivilgesellschaft,' Kommune und Staat im Kaiserreich," Geschichte und Gesellschaft 33 (2007): 10-45. Cf. Sandra Cavallo, "The Motivations of Benefactors: An Overview of Approaches to the Study of Charity," in Medicine and Charity before the Welfare State, ed. Jonathan Barry and Colin Jones (London and New York: Routledge, 1991), 46-62.
} 
General Leo von Caprivi, "It is well known that King Georg V—now his successor-and their families have uninterruptedly made not exactly insubstantial donations to philanthropic institutions in the province. One can assume that the resulting bond with the former royal family and gratitude for their contributions has a retarding impact on the province's inner amalgamation [innere Verschmelzung] with the kingdom of Prussia." 40 The historian Dieter Brosius, however, propounded the interesting and convincing thesis that the money flow from Gmunden to Hannover was not so much the cause but the symptom of a genuine rapport between benefactor and recipient. ${ }^{41}$ As the field of nursing diversified and became more competitive, the Guelph connection helped the two Lutheran philanthropic enterprises maintain a distinct corporate identity. The chaplain of the Henriettenstift expressed the work ethic and symbolic significance of the House of Guelph most succinctly when he reminded the Frederica Association's governors in 1915, "We partly do the same work in treating the poor and those in need. It is the same royal house whose name connects the establishment of our two institutions. We serve the same lord and share the same faith." 42

This special corporate identity drew strength from the juxtaposition of orthodox Lutheran spirituality and the maelstrom of Wilhelmine power politics. Pastor Kranold, chaplain to the Frederica Sisters, publicly expressed the "hidden transcript" with surprising candor at a memorial service held for Queen Marie at the Hanoverian Concert House in 1908. Following a sermon by the director of the Hermannsburg Mission, Georg Haccius, who castigated the "cold egotism" of the present and its "culture of violence and [belief in] 'one's own strength," Kranold took the pulpit to expound on the late exiled monarch's qualities as a role model.

Our queen managed to leave [all her palaces and the Lower Saxon people] without bitterness and anger, hatred for mankind, or misanthropy because she was sure of God's mercy . . .; because she considered herself a child of the Heavenly Father and heiress of the Kingdom of Heaven. The apostolic saying "our Heimat is in Heaven" was an internalized truth, source of spiritual wealth, and strength to her. She could trust in the God who gave her the Heavenly Kingdom, even though He allowed the earthly kingdom to be taken away from her. "Disciples of the saints and lodgers in God's house,"

\footnotetext{
${ }^{40}$ Steering committee of the Hanoverian children's hospital to Chancellor von Caprivi, April 18, 1891, Bundesarchiv Berlin-Lichterfelde (herafter BAB), R 43/1407, fols. 97v-98.

${ }^{41}$ Brosius, “'Allerhöchstihrer Majestät Lieblingsstiftung,"” 140. Georg Simmel's definition of gratitude bolsters Brosius's claim. He notes that gratitude is an expression of emotional agreement between benefactor and beneficiary where reciprocity is not obligatory. Georg Simmel, "Dankbarkeit. Ein soziologischer Versuch," in Georg Simmel, Aufsätze und Abhandlungen 1901-1908, vol. 2 (Frankfurt am Main: Suhrkamp, 1993), 310.

${ }^{42}$ Pastor G. Lohmann to the executive committee of the Women's Association for the Care of the Poor and Sick, July 28, 1915, Archiv des Friederikenstifts (hereafter AFS), folder "Fünfundsiebzigstes Jubiläum des Friederikenstifts."
} 
let us strive to transcend ourselves, dear compatriots. Then the earthly [world] will not dominate us but we will become its masters.

The pastor finished by saying that Marie's devotion to her husband, her motherly demeanor, and good works served as inspiration to all women. ${ }^{43}$ The veiled antiPrussian recriminations of Kranold's sermon demonstrate the intensity of orthodox Lutheran circles' objections to the violent removal of their ancestral dynasty well into the twentieth century. To them, the earthly fatherland remained tainted by the lack of moral foundations after the victory of political might in 1866.

Yet, Martin Luther's Doctrine of Two Realms drew a distinction between the autonomy of Christian faith and the legitimate exercise of state authority to maintain order in human society. ${ }^{44}$ In that sense, even the reproachable Prussian crown served a higher principle that harmonized with religious charities' concern for the welfare of their countrymen. And here the second important aspect of Kranold's speech came into play. Using Queen Marie as an example, he showed women how selfless service in the name of Christ empowered them to mature into true "patriots." Conceptually, it mattered whether charity workers put service to the earthly or the heavenly fatherland first, but in practice the distinction became increasingly difficult to maintain because the long road to God's Kingdom passed through Berlin. To achieve their goal, the Hanoverian apostles of the Inner Mission needed to work with the government, not against it. Before addressing these modes of cooperation, however, it is essential to give a clearer idea of the social space that was at the heart of religious benevolence.

Early on, the governors of the Henriettenstift and the Frederica Association decided not to disregard the brave new world of social and political transformation. Pastor Büttner, who took the reins of the Henriettenstift from Oberin Forcke in 1869, even viewed the exile of their erstwhile patrons as a divinely ordained opportunity for independent action. ${ }^{45}$ This fueled the deaconesses' ambition to extend their reach beyond Hannover. Capitalizing on its newfound popularity after Langensalza, the convent attracted a growing number of young women (1866: 29; 1896: 313; 1914: 654) who serviced society's likewise expanding demand for trained nurses. ${ }^{46}$ In the process the Henriettenstift became a

\footnotetext{
${ }^{43}$ Author unknown, Gedächtnisfeier am Todestage Ihrer Majestät der hochseligen Königin Marie von Hannover am 9. Januar 1908 im Konzerthause an der Goethebrücke in Hannover (Hannover: A. and H. Brunotte, 1908), 15, 18-19.

${ }^{44}$ Dietmar von Reeken, Kirchen im Umbruch zur Moderne. Milieubildungsprozesse im nordwestlichen Protestantismus, 1849-1914 (Gütersloh: Kaiser, 1999), 409-11.

${ }^{45}$ Wilhelm Rothert, Die innere Mission in Hannover in Verbindung mit der sozialen und provinzialen Volkswohlfahrtspflege (Gütersloh: C. Bertelsmann, 1909), 330.

${ }^{46}$ Henriettenstift, Das Henriettenstift, Ev. Luth. Diakonissen-Mutterhaus Hannover. Sein Werden und Wachsen 1860-1935 (Hannover: Henriettenstift, 1935), 37, 115.
} 
respected and major player in the care-giving industry by dispatching staff to hospitals, community nursing practices, kindergartens, home economics schools, asylums for prostitutes and the disabled, and hospices. By 1910 the deaconesses treated no fewer than 85,464 clients, not counting 2,694 motherhouse patients. ${ }^{47}$ In a show of Protestant solidarity, even East Frisians reversed their initial frostiness toward the deaconesses and invited them into their communities lest the active Catholic nurses ensconce themselves in the hospitals of the coastlands unopposed. Drawing level with its rivals, the Henriettenstift emphasized the availability of its services to everybody irrespective of religious background. The diaconal community nurses soon gained recognition for their efforts to contain potentially devastating infectious diseases such as typhoid and scarlet fever that wreaked havoc on many a German city in the nineteenth century, including nearby Hamburg. ${ }^{48}$ The Henriettenstift's sister charity, the small but effective Frederica Association and the affiliated Sisters of Frederica, whose combined membership never exceeded fifty, helped hundreds of poor families in Hannover get through the Great Depression (1875: 100; 1877: 176; 1880: 233) and on average provided healthcare to more than 100 patients per year. ${ }^{49}$

It is important to understand the reasons that young women decided to devote their lives to such a demanding profession as nursing and how they selected the right charity for them. Unfortunately, most ego-documents that could have elucidated the opinions of ordinary women were destroyed in World War II, leaving behind only fragmentary evidence. The Hanoverian historian Christiane Schröder identifies five primary incentives for this career path: income, social prestige, vocational training, self-realization within a sheltered community, and Christian selflessness. ${ }^{50}$ The insistence of Diakonie managers such as Fliedner, Uhlhorn, and Büttner that the often grueling work of nursing represented a logical extension of female domesticity put a distance between them and the rhetoric of vocational emancipation employed by the emerging middle-class women's movement. In Göttingen, tellingly, the president of the municipal women's association complained about the self-containment of Henriettenstift deaconesses, which occasionally hampered dialogue when the two sides joined

\footnotetext{
${ }^{47}$ Blätter aus dem Henriettenstift 42, nos. 3-6 (1911): 10.

${ }^{48}$ Gerhard Canzler, "Diakonissenstation in Norden. Das Tagebuch der Schwester Marie von 1878 bis 1906," Heim und Herd (Sept. 29, 2001): 33-36; Rothert, Die innere Mission, 336-39. On Hamburg, see Richard J. Evans, Death in Hamburg: Society and Politics in the Cholera Years 1830-1910 (Harmondsworth: Penguin, 1990).

${ }^{49}$ Bericht des Frauen-Vereins für Armen- und Krankenpflege im Friederikenstift zu Hannover 1875/ $1876 /$ 1877 (Hannover: Friederikenstift, 1878), 4. Bericht des Frauen-Vereins für Armen- und Krankenpflege im Friederikenstift zu Hannover für die Jahre 1878, 1879, 1880 (Hannover: Friederikenstift, 1881), 7.

${ }^{50}$ C. Schröder, "Eine neue Heimat im Mutterhaus," 39. Cf. Susanne Kreutzer, “"Before We were Always There-Now Everything is Separate': Nursing Reform in Western Germany," Nursing History Review 16 (2008): 180-200. Silke Köser, Denn eine Diakonisse darf kein Alltagsmensch sein. Kollektive Identitäten Kaiserswerther Diakonissen 1836-1914 (Leipzig: Evangelische Verlagsanstalt, 2006), 445-76.
} 
forces for the sake of local initiatives. ${ }^{51}$ Reformers fought an uphill battle because traditional non-emancipatory charity work continued to hold considerable appeal for unmarried daughters of the old Mittelstand (artisans and shopkeepers) as well as farmers, whose status came under threat as corporate gave way to industrial society. To them, religious motherhouses-Protestant and Catholicoffered a home and respectability with entitlement to a socially sanctioned place in public life. ${ }^{52}$

Given the array of different options, however, what exactly made prospective charity workers choose one motherhouse over another? A survey conducted by the Henriettenstift in 1880 exposed a tentative pattern. The majority of deaconesses came from the Hanoverian heartlands where both Pietism and Guelph loyalties had deep roots. Extant, often very emotional, letters to Queen Marie from privileged as well as low-ranking deaconesses underlined the interconnectedness of politics and religious orientation by hailing her both as a secular mother to her people (Landesmutter) and spiritual mother (Stiftsmutter).$^{53}$ A perhaps more surprising finding of the survey was that 33 non-Hanoverians and one Swiss were among the 164 convent members counted in the census. ${ }^{54}$ This sizeable "foreign" contingent, which accounted for 20.1 percent of the total membership, raises the interesting question whether Westphalians, Mecklenburgers, and Silesians watered down the Hanoverian identity of the convent or, conversely, acculturated to the Guelph corporate image. Many historians consider this query, if addressed at all, ancillary to the socioeconomic and religious reasons that induced women to join the Diakonie, yet it must have affected the latter's decisions because, as Ernst Schubert has pointed out, the Henriettenstift's Guelph connections were common knowledge in Hannover. ${ }^{55}$ The results of the statistical review mattered, for the checkered membership mirrored the struggle of Hanoverian charities to find their place in the complex political landscape of the Second Empire.

\footnotetext{
${ }^{51}$ Traudel Weber-Reich, "Um die Lage der hiesigen nothleidenden Classe zu verbessern." Der Frauenverein zu Göttingen von 1840 bis 1956 (Göttingen: Vandenhoeck \& Ruprecht, 1993), 156. On the women's movement more generally, see Reagin, A German Women's Movement, 99-122, 173-86. Richard J. Evans, The Feminist Movement in Germany, 1894-1933 (London: Sage, 1976), $1-113$.

${ }^{52}$ Rebekka Habermas, "Weibliche Religiosität—oder: Von der Fragilität bürgerlicher Identitäten," in Wege zur Geschichte des Bürgertums, ed. Klaus Tenfelde and Hans-Ulrich Wehler (Göttingen: Vandenhoeck \& Ruprecht, 1994), 125-48.

${ }^{53}$ See, for instance, letter from Sister Linchen Wagner to Queen Marie, July 26, 1881, NHStAH, Dep. 103 XXI, Nr. 1004, fol. 158. The author gratefully acknowledges the permission of His Royal Highness Prince Ernst August of Hanover to access the letters in this deposit.

${ }_{54}^{5}$ Blätter aus dem Henriettenstift, no. 12 (1880): 47.

${ }^{55}$ Ernst Schubert, "Verdeckte Opposition in der Provinz Hannover. Der Kampf der 'Welfen' um die regionale Identität während des Kaiserreichs," Blätter für deutsche Landesgeschichte 134 (1998): 261-62.
} 
The late 1860s and 1870s saw much vacillation, with relations between religious charities and the state improving until the end of the Franco-Prussian War and then deteriorating again during the Culture War. The Guelph associations of Lutheran benevolence boded ill, as the Henriettenstift discovered when the executive committee applied in 1869 to the ministry of public worship for official recognition as a parish (Personal-Parochie). The minister at the time, Heinrich von Mühler, turned down the request, as did his successor Adalbert Falk three years later, on account of the committee's ties to the exiled royal family of Hanover. ${ }^{56}$ This punishment cemented the inferior ranking of Büttner and his successors to much less eminent parish pastors in the church hierarchy, although the committee of the Henriettenstift made up for the social slight by paying them twice the salary of their colleagues. ${ }^{57}$

Female charities all the same impressed the authorities with their display of patriotic fervor during the Franco-Prussian War, regardless of their denominational and political affiliation. The wives of Hanoverian and Prussian notables in the Patriotic Women's Association (PWA) collaborated harmoniously with each other, collecting bandages and gifts for the soldiers on the front or looking after soldiers in auxiliary military hospitals closer to home. On the recommendation of district presidents, who were careful to nominate Hanoverian and Prussian candidates in equal measure, Kaiser Wilhelm I awarded no fewer than forty of Empress Augusta's coveted Merit Crosses in 1871 to members of the PWA's Hanover branch. ${ }^{58}$

Not to be outdone, eighteen Catholic sisters from Hildesheim also joined military hospitals close to the French border, for which all of them received a commemorative medal and their reverend mother the Merit Cross. ${ }^{59}$ Their conduct was not entirely unexpected. Unlike their Lutheran opposite numbers, the upper leadership positions in the nursing order were firmly in the hands of Prussian natives during the difficult phase of national unification. Moreover, half the sisters hailed from outside the province. ${ }^{60}$ Their commitment to the PrussoGerman war effort may therefore have seemed the most appropriate application of Christian charity, especially since the sisters and the army shared a common

\footnotetext{
${ }^{56}$ Ernst Schering, "Johannes Schwerdtmann. Ein bedeutender Mann der Kirche und der Diakonie Hannovers zu Beginn des 20. Jahrhunderts," Hannoversche Geschichtsblätter NF 43 (1989): 139; Blätter aus dem Henriettenstift, no. 9 (1879): 35.

${ }^{57}$ Blätter aus dem Henriettenstift, no. 9 (1879): 35.

${ }^{58}$ Die königliche Haupt- und Residenzstadt Hannover. Festschrift zur Einweihung des Rathauses im Jahre 1913 (Hannover: Gebrüder Jänecke, 1913), 148. For commentaries on award recommendations, see NHStAH, Hann. 180 Hildesheim, Nr. 1123.

${ }^{59}$ Sterner, Kongregation der Barmherzigen Schwestern, 63.

${ }^{60}$ The present author relies here on statistics graciously supplied by the archivist of the Congregation of the Sisters of Charity in Hildesheim, Sr. Regina-Maria. In 1866 slightly less than half of the sisters were natural-born Hanoverians. The balance shifted somewhat in their favor later, adding up to an average ratio of six to four for the period 1852-1914.
} 
modus operandi built on order and discipline. One of the sisters from Hildesheim, in fact, gained some notoriety with the soldiers because her gait resembled that of a Prussian officer and her tone of command that of a sergeant. ${ }^{61}$

The Henriettenstift's unreserved endorsement of the war, on the other hand, may have seemed incongruent with the unequivocal distance of its executive committee and royal patroness from the kleindeutsch nation. As shown earlier, however, the convent's publicity boost after Langensalza pulled the deaconesses into a solidifying partnership with the Hohenzollern monarchy's male warrior culture. ${ }^{62}$ Any doubts about the justness of Bismarck's actions in 1870 were dispelled by the chronological overlap of France's ostensible aggression and the proclamation of the papal Dogma of Infallibility. The imagined unholy union between Napoleon III, the Catholic protector of Rome, and Pope Pius IX activated the Protestant instinct for self-preservation. After Catholicism's "declaration of war against Christ," Büttner's Blätter aus dem Henriettenstift vowed "to put our limited energies in the service of wartime nursing for the glory of our Lord." 63 Interestingly enough, Büttner's anti-ultramontane outburst appears to have been primarily for "domestic consumption" because there was little evidence of a Catholic backlash. This in no way diminished the electrifying effect of his call to arms. The convent immediately went about putting its "limited energies" to use by training eighty to one hundred women "of all stations from town and country" as auxiliary nurses and dispatching regular deaconesses to military hospitals in Darmstadt, Remily, Kusel, Zweibrücken, and Hannover. Meanwhile, "friends" of the Henriettenstift helped to cope with the influx of wounded army personnel at the convent itself. ${ }^{64}$

The budding cooperation between the Prussian state and Hanoverian religious nursing charities was nevertheless soon interrupted. Bismarck's Culture War legislation, in bolstering the powers of the secular state vis-à-vis the social and political influence of the churches, did not win him any friends in the Diakonie convent or the Frederica Association. Even harder hit were the Catholic sisters. The Prussian Monastery Law of May 1875 dissolved all orders and congregations except for those devoted to the care of the old and infirm. Although covered by the exemption, the Sisters of Charity were forced to give up their involvement in

\footnotetext{
${ }^{61}$ Thomas Scharf-Wrede, Für den Menschen. 150 Jahre Kongregation der Barmherzigen Schwestern vom hl. Vinzenz von Paul in Hildesheim (Hildesheim: Bistum Hildesheim, 2007), 13.

${ }^{62}$ On the complementary relationship between female charity and military masculinity in Prussia, see also Karen Hagemann, "A Valorous Volk Family: The Nation, the Military, and the Gender Order in Prussia in the Time of the Anti-Napoleonic Wars, 1806-15," in Gendered Nations, ed. Blom, Hagemann, and Hall, 179-205; Karen Hagemann, "Männlicher Muth und Teutsche Ehre." Nation, Militär und Geschlecht zur Zeit der Antinapoleonischen Kriege Preußens (Paderborn: Schöningh, 2002).

${ }^{63}$ Blätter aus dem Henriettenstift, no. 5 (1870): 2. See also Thomas Nipperdey, Religion im Umbruch. Deutschland 1870-1918 (Munich: Beck, 1988), 96.

${ }^{64}$ Pastor Büttner to Marianne von Hartmann, Aug. 3, 1870, NHStAH, Hann. 91 v. Hartmann, Nr. 13, fols. 323-23v; Henriettenstift, Das Henriettenstift, 74.
} 
public education and the running of orphanages. Sisters recalled to the motherhouse from then on spent their days producing altar decorations for lack of other employment opportunities. ${ }^{65}$ Until the end of the Culture War in 1886 membership figures stagnated; new admissions had to be individually approved by the authorities who, worst of all, subjected the sisters to the same periodic police questioning normally reserved for prostitutes. ${ }^{66}$

Neither party forgot this dark stain on the record of Prussian state building too quickly, but the realization prevailed that cooperation on the premise of giveand-take benefited everybody in the long term. The Catholic sisters drew a distinction, at any rate, between the instigator of the repressive Culture War, Bismarck, and the Hohenzollern court. Empress Augusta achieved iconic status when she defied her husband's chief minister by employing Catholic nurses in her private chambers. ${ }^{67}$ Regardless of whether they sympathized with the Hohenzollern regime, charities competed for patronage, and staying on top of the shifting political currents was pivotal. For instance, the magistrate of Hannover initially favored the Catholic nurses after the events of 1866 because Stadtdirektor (Mayor) Hermann Rasch mistrusted the Henriettenstift's nonetoo-subtle backing of the strict orthodox wing of the Lutheran church (which invariably implied Guelph sympathies). The onset of the Culture War turned the status quo upside down and made the deaconesses trade places with their Catholic counterparts in the city fathers' good graces. ${ }^{68}$ The Frederica Association and the Henriettenstift relied especially on external funding since their income remained insufficient to cover all expenditures and necessary infrastructural upgrades. In 1877 the latter was the tenth largest Diakonie motherhouse in the Kaiserswerth Confederation, but only ranked fourteenth in terms of income. Despite an overall improvement in the Henriettenstift's finances in subsequent decades, the picture looked remarkably similar shortly before the outbreak of World War I. ${ }^{69}$ The Frederica Association, albeit operating on a smaller scale, also only just broke even in most years. ${ }^{70}$

The central, provincial, and municipal administrations depended on the services of trained nurses just as much as the charities needed sponsors to survive. Tellingly, the minister of war, General Georg von Kameke, reminded his king

\footnotetext{
${ }^{65}$ Author unknown, "Blumen. Erzählungen aus dem erbaulichen Leben und Wirken verstorbener Schwestern aus der Kongregation vom hl. Vinzenz von Paul in der Diözese Hildesheim," unpublished chronicle (1938), Archiv der Barmherzigen Schwestern in Hildesheim, 25-26.

${ }^{66}$ Sterner, Kongregation der Barmherzigen Schwestern, 64-67; Jahrbuch der Hannoverschen Volkszeitung. Katholisches Handbuch der katholischen Pfarrgemeinden in den Städten Hannover und Linden u. ganz Nordhannover (Hannover: J. Kornacker, 1912), 49-50.

67"Blumen," 27.

${ }^{68}$ Rothert, Die innere Mission, 329.

${ }^{69}$ Blätter aus dem Henriettenstift, no. 9 (1878): 3; Blätter aus dem Henriettenstift 44, nos. 9 and 10 (1913): 36.

${ }^{70}$ See published annual financial reports of the Frederica Association, held by the Gottfried Wilhelm Leibniz Bibliothek in Hannover.
} 
during the crucial cabinet session to approve the anti-Catholic May Laws of 1875 that Prussia could not wage war without the participation of religious nursing orders. ${ }^{71}$ Similarly, Kaiser Wilhelm II and his wife Auguste Viktoria valued the community nursing program of the Diakonie as a useful and relatively cheap weapon against social strife. ${ }^{72}$ The chief executive officer (Landesdirektor) of the province's public works agreed. "The accomplishments of the Henriettenstift," Baron Ernst von Hammerstein-Loxten summed up his assessment before the Hanoverian provincial diet in 1899, "are, as is well known, in many respects hugely beneficial." 73 The parliamentarians needed little convincing to maintain public funding for the convent as well as the Frederica Association and the Sisters of Charity. ${ }^{74}$ Furthermore, the Lutheran consistories gave pastors permission to collect donations for charities in their churches, and the affluent magistrate of Hannover helped out the Frederica Association with extra donations and substantial loans in times of need. ${ }^{75}$

Dependence on outside funding and goodwill created an obligation not to bite the hand that feeds. Therefore, when the former Hanoverian minister Ernst Unico von Malortie resigned from the chairmanship of the Henriettenstift's executive committee in 1883, Hartmann advised her royal mistress to be "as clever as a snake" by going the way of least resistance. Queen Marie agreed with this logic and dropped her favored choice, Dr. Ludwig Brüel, because this prominent German Hanoverian Party (DHP) politician was persona non grata in Berlin. ${ }^{76}$ In the same vein the governors of the deaconesses' convent and the Frederica Association were at pains not to show any political colors, even in private correspondence with members of the exiled royal family. The language of political ambiguity, which sustained the hidden Hanoverian transcript, diplomatically indulged the duke of Cumberland's hopes for a return of his dynasty to

\footnotetext{
${ }^{71}$ Johannes Maring, Die Kongregation der barmherzigen Schwestern vom heiligen Vinzenz von Paul in Hildesheim (Hildesheim: Lax, 1908), 19. Cf. Christoph Schweikardt, "Cholera and Kulturkampf: Government Decision Making and the Impetus to Establish Nursing as a Secular Occupation in Prussia in the 1870s," Nursing History Review 16 (2008): 101.

${ }^{72}$ Jutta Schmidt, Beruf. Schwester, Mutterhausdiakonie im 19. Jahrhundert (Frankfurt am Main and New York: Campus, 1998), 226-28.

${ }^{73}$ Protokolle des 24. Hannoverschen Provinziallandtags, twelfth session, Jan. 17, 1899, 202.

${ }^{74}$ Brosius, “"Allerhöchstihrer Majestät Lieblingsstiftung,"” 140. Regular and irregular subsidies amounted annually to 4-5,000 RM for the deaconesses and about 600-1,500 RM each for the other two institutions between 1869 and 1910. Protocols of the Hanoverian provincial diet, NHStAH, Hann. 150, Nr. 571, fols. 4v-12v, 39, 45.

${ }^{75}$ Bericht des Frauen-Vereins für Armen- und Krankenpflege im Friederikenstift zu Hannover für das Jahr 1908 (Hannover: Friederikenstift, 1909), 7. In 1876 the Frederica Association took out a loan of 90,000 RM from the magistrate which was amortized eighteen years later. Certified statement signed by magistrate syndic and Deputy Mayor Eyl, June 16, 1894, AFS, folder "Grundstücksangelegenheiten 1876-1927." See also Frauenverein für Armen- und Krankenpflege, Die ersten fünzig Jahre des Friederikenstifts 1840-1890 (Hannover: Feesche, 1890), 23.

${ }^{76}$ Hartmann to Queen Marie, August 14, 1883, NHStAH, Dep. 103 XXI, Nr. 1004, fol. 18v. Brosius, “"Allerhöchstihrer Majestät Lieblingsstiftung,” 140.
} 
the ancestral throne without explicitly committing the Lutheran charities to the corollary and, in the eyes of the Prussians, subversive agenda of the anti-annexationist DHP. ${ }^{77}$ For instance, although the matron of the Frederica Association, Marie Lichtenberg, congratulated the duke on the birth of an heir in 1880 and asked God to realize through him "all the hopes which many thousand Hanoverians pray for today together with the happy parents," she implied that it was up to divine providence, and not the Sisters of Frederica, to carry out the ambitions of the Guelphs. ${ }^{78}$

The authorities continued to monitor charities closely for signs of political sedition, as evidenced by the fact that the provincial governor kept a file on Büttner because of his close ties to Gmunden and the alleged public display of his Guelph sympathies at Lutheran synods. ${ }^{79}$ On the other hand, the government also generously rewarded loyal personal service to the Prussian state. For the Henriettenstiff's fiftieth anniversary in 1910, the governor of Hanover himself graced the festivities with his presence to bestow the Third and Fourth Class of the Order of the Red Eagle respectively on the most distinguished executive committee member, the chaplain, and the two chief surgeons. Significantly, such largesse in the doling out of medals did not extend to women in peacetime. The abbot of Loccum, Uhlhorn's successor, acknowledged the achievements of deceased matrons in a laudatory speech, but the present Oberin and the other 500 -odd female members of the convent would have waited in vain for personal tokens of appreciation from the Kaiser. ${ }^{80}$ Be that as it may, the public honoring of the charity and the promotion of Johannes Schwerdtmann, Büttner's successor, to the position of superintendent-general of Stade two years later demonstrated growing trust in the political reliability of the Henriettenstift. ${ }^{81}$

These official seals of approval, in turn, were an important asset that improved the convent's marketability across the political trenches. National Liberal notables and their wives in the most nationalistic female organization, the PWA, proved receptive because they shared the diaconal philosophy of relief provision for the sick, disabled, orphaned, and poor within a social framework that reinforced traditional, non-emancipatory gender roles. ${ }^{82}$ Present in the province of Hanover

\footnotetext{
${ }^{77}$ The Friederikenstift did receive reading material from the DHP, but the available archive files in Hannover leave it unclear whether staff acted on it.

${ }^{78}$ Marie Lichtenberg to the duke of Cumberland, Nov. 21, 1880, AFS, folder "Geldgeschenke und Vermächtnisse."

${ }^{79}$ NHStAH, Hann. 122a, Nr. 2749, fol. 216.

${ }^{80}$ Hannoverscher Anzeiger, June 28, 1910, 2.

${ }^{81}$ Ernst Rohde, Prediger und Seelsorger. Lebensbilder hannoverscher Pastoren (Hannover: Feesche, 1962), 42-43.

${ }^{82}$ To be sure, Roger Chickering has shown persuasively that sometimes "women who styled themselves patriots attempted to broaden the purview of their public roles in a way which brought them in conflict with male patriots," but the Patriotic Women's Association on the whole subscribed to thoroughly traditional gender roles-just like the Diakonie. Roger Chickering, "Casting their
} 
since 1867, this organization could count on the backing of the political establishment and therefore had considerable financial means at its disposal. The leadership felt more comfortable engaging with issues of charity management than the mundane nitty-gritty of social work, as Dietlinde Peters has shown, while the Henriettenstift offered much-needed technical know-how and hands-on experience. ${ }^{83}$ Due to these complementary assets it was only a small step to the symbiotic community-nursing partnerships that came about in some towns after 1900 . The local PWA branches in Fallingbostel, Lehrte, Northeim, and Uelzen collected money for the creation of nursing stations, while fellow PWA members in Duderstadt, Osterode, and Peine agreed to pay the wages of Henriettenstift staff or contributed to their upkeep in these towns. In Clausthal the two sides came to a "harmonious" arrangement whereby the lay nurse employed by the PWA supported the Lutheran charity workers, whereas the diaconal community nurse in Lauterberg am Harz agreed to teach home economics in the PWA-run municipal knitting and mending school. ${ }^{84}$

It was symptomatic of the two charities' intensifying collaboration that when the provincial headquarters of the PWA opened a treatment center for children with tuberculosis in May 1910, Pastor Schwerdtmann of the Henriettenstift was selected to hold the dedication speech in front of eminent guests from Hannover and Berlin. ${ }^{85}$ As the bonds between the erstwhile Guelph charity and patriotic benevolence tightened, so did the dynastic presence of the Hohenzollerns in the deaconesses' working environment. In Bad Essen in the district of Osnabrück, for example, church elders decided to mark the imperial couple's silver wedding anniversary in 1906 with a donation for the construction of a second wing at the Henriettenstift-run care center. The occasion that had prompted such munificence was appropriately commemorated with a wall mural outside the new wing; clearly visible even to nearsighted spectators, new patients were greeted with a large image of the imperial crown over the initials and wedding anniversary date of the exalted couple. Louder than words, the mural attested to the transcendental qualities that Hohenzollern symbolics of power acquired over time where they were linked to philanthropy. ${ }^{86}$

Gaze More Broadly': Women's Patriotic Activism in Imperial Germany," Past and Present 118 (1988): $160,163$.

${ }^{83}$ Dietlinde Peters, Mütterlichkeit im Kaiserreich. Die bürgerliche Frauenbewegung und der soziale Beruf der Frau (Bielefeld: Kleine Verlag, 1984), 157-58.

${ }^{84}$ Schwerdtmann, Das Henriettenstift und seine Arbeitsgebiete, 47, 50-2, 123, 182-3, 185, 191, 216, 309.

${ }^{85}$ Verband der Vaterländischen Frauenvereine der Provinz Hannover, Verwaltungs-Bericht für das Jahr 1910 (Hannover: Culemann, 1911), 7.

${ }^{86}$ Schwerdtmann, Das Henriettenstift und seine Arbeitsgebiete, 294. On the workings of royal symbolics of power, see also Clifford Geertz, "Centers, Kings, and Charisma: Reflections on the Symbolics of Power," in Culture and Its Creators: Essays in Honor of Edward Shils, ed. Joseph Ben-David and Terry Nichols Clark (Chicago and London: The University of Chicago Press, 1977), 150-71, esp. 153. 
Pragmatic as it was, the complicity of the Hanoverian Diakonie in this imperial memory cult was only partially fed by a hunger for money or official recognition. Rather, Uhlhorn, Büttner, and their coreligionists in the Frederica Association needed powerful allies to implement the religious agenda of the Inner Mission. They regarded Catholic nurses as their main rivals because of the intense competition for patrons as well as perceived antithetical spirituality. Fundamentally, Uhlhorn held in accordance with Lutheran soteriology that Protestant women performed good works as a token of their gratitude for divine grace; their Catholic counterparts, on the other hand, were seen to "reduce" the same to a vehicle for personal salvation. ${ }^{87}$ At a conference of Diakonie experts convened by the empress in Berlin in 1889, Hanover's chief Lutheran theologian added that the sisters were "machines" who did the most demeaning tasks in a bid to impress unsuspecting Protestant populations. Because they only served to elevate the souls of the benefactors and to win converts, Catholic good works killed off all self-initiative and lulled patients into laziness, he continued, whereas deaconesses' well-judged intervention in genuine medical emergencies provided a service of true humanity. ${ }^{8}$

Uhlhorn's stark rhetoric belonged in the context of resurgent criticisms leveled against female deaconry from two very different quarters at the end of the nineteenth century. Discontents within the Lutheran church charged that the organizational makeup of motherhouses not only resembled nunneries but that diaconal charity raised itself above secular callings in a "Catholic" fashion. ${ }^{89}$ Social reformers in the General German Women's Association (Allgemeiner Deutscher Frauenverein), who were concerned with expanding vocational opportunities for women, shared Lutheran critics' reservations about the diaconal work ethic because the self-imposed "martyrdom" of devoutly confessional nurses was considered a pretext for their physical exploitation..${ }^{90}$ These weighty accusations put proponents of Diakonie on the defensive. In their eyes Empress Auguste Viktoria's emphatic sponsorship of Protestant charity in general and the

\footnotetext{
${ }^{87}$ Gerhard Uhlhorn, Schriften zur Sozialethik und Diakonie (Hannover: Lutherisches Verlagshaus, 1990), 475-88, here 478.

${ }^{88}$ Weber-Reich, "Wir sind die Pionierinnen der Pflege," 102-3. Protokoll über die auf Befehl Ihrer Majestät der Kaiserin und Königin am 5. und 6. Dezember 1889 stattgehabte Berathung über die Frage: was kann geschehen, um die Zahl der Diakonissen dem Bedürfniß entsprechen zu vermehren?, 4-6, copy of published protocols in NHStAH, Hann. 122a, Nr. 3626.

${ }^{89}$ In 1893/94 Uhlhorn and the theology professor Alexander von Oettingen at Dorpat University entered a high-publicity debate on the Catholic origins of the motherhouse idea. Uhlhorn did not deny them, but conceded that the Diakonie needed to "progressively exorcize Catholicizing influences." Inke Wegener, Zwischen Mut und Demut. Die weibliche Diakonie am Beispiel Elise Averdiecks (Göttingen: Vandenhoeck \& Ruprecht, 2004), 150-60, here 155.

${ }^{90}$ See, for instance, Mathilde Weber, "Ueber die Ursache des Mangels an Diakonissen," Neue Bahnen, Feb. 13, 1893, 25-28. Ellen Ueberschär, "Sozialer Protestantismus und Frauenfrage," in Sozialer Protestantismus im Kaiserreich. Problemkonstellationen-Lösungsperspektiven-Handlungsperspektiven, ed. Norbert Friedrich and Traugott Jähnichen (Münster: LIT Verlag, 2005), 60.
} 
opening of more diaconal community nursing stations in particular therefore went a long way in restoring the government's tarnished moral reputation. After appointing herself patroness of female deaconry in Germany, the empress was welcomed with unprecedented warmth when she later visited the Henriettenstift. In honor of the occasion, the convent's in-house news bulletin broke its customary silence on current affairs to praise her interest in the cause of the Diakonie, "heartfelt sympathy" for the sick, and "radiating" friendliness. ${ }^{91}$

Hanoverian charities probably never forgot that a more sinister shadow world of unspoken threats and backroom dealing lurked beneath the friendly public face of Hohenzollern patronage. If the Henriettenstift or the Frederica Association would not play ball, others certainly would. The Sisters of Charity went from strength to strength in Hanover and the rest of Germany after the termination of the Culture War. In 1911-12 the congregation promised to put thirteen hospitals owned by the congregation and 145 sisters at the disposal of the fatherland in the event of war. ${ }^{92}$ The Wilhelmine Age similarly saw the proliferation of a plethora of women's organizations. The provincial capital became home to a flourishing movement of female activism-between 1890 and 1906 more new societies (nineteen) came into being than in the previous eighty years taken together (fifteen). ${ }^{93}$ In qualitative terms, too, these associations were a major addition to the existing philanthropic infrastructure. Not content to treat merely the symptoms of poverty and disease, the new generation of clubwomen began to turn their gaze from charity to systematic social work. Whereas previous poor relief targeted moral reform of the individual, late nineteenth-century social knowledge viewed the individual less as a moral free agent than an embodied subject constrained by material reality. ${ }^{94}$

The Protestant Women's Association (Deutsch-evangelischer Frauenbund, or DEF), which had its national headquarters in Hannover since 1901, is a case in point. Like the Frederica Association and the Henriettenstift, the DEF grew out of the Inner Mission. It campaigned for women's suffrage in municipal and

\footnotetext{
${ }^{91}$ Blätter aus dem Henriettenstift 41, nos. 9 and 10 (1910): 24-25; Norbert Friedrich, "Die Christlichsoziale Bewegung und Wilhelm II.," in Wilhelm II. und die Religion. Facetten einer Persönlichkeit und ihres Umfelds, ed. Stefan Samerski (Berlin: Duncker and Humblot, 2001), 111-12. In 1899 Auguste Viktoria and like-minded conservatives close to the imperial court called into being the Frauenhilfe, a self-consciously Protestant charitable organization (in contradistinction to the "supraconfessional" PWA) that collected money for diaconal community nursing. Jahrbuch. Frauenhülfe des Evangelisch-Kirchlichen Hülfsvereins (1909), 7. Baumann, Protestantismus und Frauenemanzipation in Deutschland, 139-49.

${ }^{92}$ Sterner, Kongregation der Barmherzigen Schwestern, 69-70.

${ }^{93}$ Reagin, A German Women's Movement, 133-34.

${ }^{94}$ Larry Frohman, Poor Relief and Welfare in Germany from the Reformation to World War I (Cambridge: Cambridge University Press, 2008), 6. Cf. George Steinmetz, Regulating the Social: The Welfare State and Local Politics in Imperial Germany (Princeton, NJ: Princeton University Press, 1993), 188-214.
} 
church council elections in addition to founding the first college for female social workers in Germany, the Christlich-Soziale Frauenschule (CSF). The overarching goal of these initiatives was to open new careers to bourgeois women in public welfare. To this end the DEF formed working groups, which, among other services, dispensed free legal advice, helped prostitutes find alternative employment, advised the magistrate on the running of orphanages, and assisted poor expectant mothers. ${ }^{95}$ Although DEF members projected a conservative outlook and rhetorically underlined the interdependence of social work and women's traditional role as nurturers, their very interest in the "woman question" laid the foundation for the reconciliation of older political disagreements. Tellingly, the DEF brought together activists from families with Guelph, National Liberal, and Conservative connections who worked harmoniously alongside each other. ${ }^{96}$

These advances in "organized motherliness" (Irene Stoehr) reflected municipal social services' increasing reliance on female input. ${ }^{97}$ The magistrate of Hannover, for one, collaborated with clergy and civic associations in founding the Voluntary Poor Relief Association in 1885, which, comprising a majority of women volunteers, supported municipal almoners by coordinating almsgiving and investigating all recipients of charity in their parishes. Traditionalists watched the reconfiguration of bourgeois female benevolence with mixed emotions. Honoring their shared commitment to the Inner Mission, the Henriettenstift agreed to teach CSF students nursing, yet it also perceived the interrelated professionalization of female social work and care-giving as a catalyst for the erosion of charity's spiritual imperative by forcing hospitals to invest more time in practical instruction. Federal and Prussian legislation, which introduced mandatory exams for nurses in 1906-07, strengthened the case for reform. Diaconal motherhouses cooperated grudgingly since, from their vantage point, Bildung led women down the dangerous road to social emancipation paved by their critics in the women's movement. ${ }^{98}$

\footnotetext{
${ }^{95}$ Königliche Haupt- und Residenzstadt Hannover, 147-48. Halgard Kuhn, "Die Gründung der Christlich-Sozialen Frauenschule (C.S.F.)," in Verantwortung für die Mitgestaltung des Sozialen in der Gesellschaft, ed. Ulrike Krause, Halgard Kuhn, and Horst Exner (Hannover: Deutscher Evangelischer Frauenbund, 2005), 31. The author wishes to thank Halgard Kuhn for generously sharing her vast knowledge about the multifaceted history of the DEF with him.

${ }^{96}$ Reagin, A German Women's Movement, 48.

${ }^{97}$ Irene Stoehr, “'Organisierte Mütterlichkeit.'Zur Politik der deutschen Frauenbewegung um 1900," in Frauen suchen ihre Geschichte. Historische Studien zum 19. und 20. Jahrhundert, ed. Karin Hausen, 2nd ed. (Munich: Beck, 1987), 221-49. Cf. Christoph Sachße, Mütterlichkeit als Beruf. Sozialarbeit, Sozialreform und Frauenbewegung 1871-1929 (Weinheim: Beltz, 2003); Iris Schröder, "Wohlfahrt, Frauenfrage und Geschlechter. Konzeptionen der Frauenbewegung zur kommunalen Sozialpolitik im Deutschen Kaiserreich 1871-1914,” Geschichte und Gesellschaft 21 (1995): 368-90.

${ }^{98}$ Susanne Kreutzer and Traudel Weber-Reich, Kultur des Pflegens. Eine Zeitreise durch 145 Jahre Pflegegeschichte der Henriettenstiftung (Hannover: Diakonissenmutterhaus der Henriettenstiftung, 2005), 40-44; Weber-Reich, "Wir sind die Pionierinnen der Pflege," 105-6. The members of the DEF branch in Hannover in fact repaid in kind for the indifferent, if not resentful, reception they got from existing local women's organizations. Cf. Marie Pagenstecher, "Die Entstehung des
} 
The Henriettenstift had little room for maneuver, however. Deep-seated worries about the superior professionalism of Catholic nurses made concessions to female Bildung, such as the implementation of a medical training curriculum for deaconesses in 1908, a condition of its continuing competitiveness. This adaptive streak in Hanoverian charity work also had political reasons. It was widely known that Bismarck and for a while his successor, Caprivi, drew on the sequestrated private assets of the Guelphs - the infamous and substantial Welfenfonds - to pay secret subsidies to prussophile hospitals. ${ }^{99}$ More importantly, the government found support among conservative women close to the political establishment for whom loyalty was not a trade-off but the prize itself. Just as the Henriettenstift and the Frederica Association combined religious service with devotion to the memory of the Guelphs, others wrote kleindeutsch patriotism into their mission statement. The deaconesses started to feel the heat when the Saxon noblewoman Baroness Olga von Lützerode opened a new nursing hospital, the Clementinenhaus, in the provincial capital four years after the Franco-Prussian War. She filled a market niche, one chronicler later explained, since the deaconesses tended to the poor, which left the "poor rich" inadequately provided for. Catholic by birth but a Lutheran convert by choice, Lützerode projected a religious but nevertheless interdenominational image. Her spiritually infused notion of politics leaned unmistakably toward nationalism and the Hohenzollerns. She considered it a privilege "in this momentous time of unified Germany's rebirth - the rebirth of a new German Empire- to be able and permitted to serve the fatherland, the heavenly and earthly kings at the same time, in an ever so modest capacity." 100

Unsurprisingly, Guelph-minded segments of Hanoverian society (who, it seems safe to assume, included the diaconal competition) openly accused the Clementinenhaus of being a "politically motivated venture" and an agent of despised confessionless "humanitarianism." allegiance to the empire had the effect of quickly endearing her to the Association for the Care of Wounded and Sick Warriors and the PWA. Soon, too, the imperial couple and the Prussian minister of public worship, Gustav von Goßler, started to take notice of Lützerode's work. ${ }^{102}$ To cement these relationships, the

\footnotetext{
Deutschen Evangelischen Frauenbundes und der Ortsgruppe Hannover," Archiv der Deutschen Frauenbewegung, Kassel, box "Ortsverband Hannover: Journal/Berichte."

${ }^{99}$ See successful request for financial assistance from the Welfenfonds by the executive committee of the Hanoverian children's hospital to Chancellor Caprivi, dated April 18, 1891. The chairman made that request, as he pointed out, because of the government's generous subsidies to other Hanoverian charities in previous years. BAB, R43/1407, fols. 97v-98v, 111.

${ }^{100}$ Lützerode cited in Weber-Reich, "Wir sind die Pionierinnen der Pflege," 119.

${ }^{101}$ Agnes Willms-Wildermuth, Die 25-jährige Geschichte des Clementinenhauses von 1875 bis 1900 (Hannover: Schlüter, 1901), 9. Weber-Reich, "Wir sind die Pionierinnen der Pflege," 123. "Clementinenhaus und Diakonissensache," Hannoversches Sonntagsblatt, July 21, 1878, 234.

${ }^{102}$ Willms-Wildermuth, Die 25-jährige Geschichte des Clementinenhauses, 10-13, 15.
} 
enterprising matron inducted the Clementinenhaus into the Red Cross, which stood under the protection of Empress Augusta. In return, the Red Cross and the PWA received seats on the supervisory board of the charity, as did later the governor of the province, the mayor of Hannover, and other high-ranking officials. What emerged was an interlocking system of power sharing, cooperation, and surveillance in patriotic benevolence. ${ }^{103}$ The upside for Lützerode and her nurses was financial security. For instance, when the Clementinenhaus needed funding for the construction of a new wing at its hospital in Hannover in 1906, the governor and the magistrate donated substantial sums of money in addition to 10,000 RM from the Kaiser. ${ }^{104}$

The enmity of Guelphs and Hohenzollerns notwithstanding, the methods their female consorts used to curry favor with the people were remarkably similar, which may go some way toward explaining why Empress Auguste Viktoria achieved growing popularity among the deaconesses after the death of Queen Marie in 1907. The empress, just like Queen Marie, attempted to insinuate herself into the corporate image of female benevolence as a Landesmutter of Christian integrity. On the occasion of the Clementinenhaus's twenty-fifth anniversary in 1900, Auguste Viktoria bestowed a large silver medal bearing the likeness of herself and a portrait of the Red Cross's first patroness, Empress Augusta, on Lützerode. ${ }^{105}$ In an act also reminiscent of Queen Marie's symbolic gift to her deaconesses in 1867, Wilhelm II's spouse underlined her aptitude as spiritual patroness by presenting the Clementinenhaus in 1903 with a large crucifix from the imperial majolica factory in Cadinen. ${ }^{106}$ The empress's acts of feminine generosity helped to promote a potent myth that offset some of the negative publicity surrounding Hohenzollern rule. As Isabel V. Hull has suggested, where the Kaiser succumbed to private amusements, showy ostentation, and ruthless Machtpolitik, the Kaiserin's seeming sincerity, piety, and devotion to duty shone through all the brighter. ${ }^{107}$

\footnotetext{
${ }^{103}$ Ibid., 17. The German Red Cross, however, saw no need to apologize. In 1907 a member of the executive committee pointed out that the high frequency of "personal unions" evident in the civil service and Red Cross hierarchies was "exceedingly conducive to keeping alive popular patriotic consciousness and furthering the Red Cross idea among the princes and the people." Executive committee member von Pannwitz cited in Andrea Süchting-Hänger, Das "Gewissen der Nation." Nationales Engagement und politisches Handeln konservativer Frauenorganisationen 1900 bis 1937 (Düsseldorf: Droste, 2002), 37.

${ }^{104}$ Jahresbericht der Provinzial-Krankenpflegerinnen-Anstalt Clementinenhaus zu Hannover für 1906 (Hannover: Clementinenhaus, 1907), 3-4.

${ }^{105}$ Olga von Lützerode, Bericht für das Jahr 1900. Dem Aufsichtsrath und Vorstande des Clementinenhauses (Hannover: Clementinenhaus, 1901), 14.

${ }^{106}$ Jahresbericht des Clementinenhauses betreffend das Jahr 1903 (Hannover: Clementinenhaus, 1904), $8-9$.

${ }^{107}$ Isabel V. Hull, The Entourage of Kaiser Wilhelm II, 1888-1918 (Cambridge: Cambridge University Press, 1982), 18. Cf. Georg Wagner-Kyora, "'Beruf Kaiserin.' Die mediale Repräsentation der preußisch-deutschen Kaiserinnen 1871-1918," Historische Anthropologie 15 (2007): 360-71.
} 
The sisters of the Hanoverian Red Cross fully requited the ideal of female patriotism and piety that the empress embodied. Lützerode threw her full weight behind nationalism and the quest for empire because here women could play a part in fulfilling Germany's historical mission. ${ }^{108}$ Between 1889 and 1893 she dispatched seven nurses to East Africa to tend to the German forces there. The devastating effect of tropical diseases forced them to leave the colony, but the annual report for that year noted wistfully, "The Clementinenhaus will always remember with joy and gratitude that it was permitted to participate for a short while in the great cultural mission that our fatherland has begun in Africa." 109 The Henriettenstift, on the other hand, entertained no such narrowly national sense of mission. The deaconesses put religious service first, and the convent's board of governors came to the conclusion that there was greater need for their missionary talents in British India than the savage hinterlands of the German possession. Stemming from their experiences in 1866, the decision makers in the Henriettenstift could perhaps still not quite shake off the feeling that secular loyalties were ephemeral. ${ }^{110}$ Furthermore, whereas Lützerode carried herself as a managerial matron and female entrepreneur, Uhlhorn and Büttner promoted clerical patriarchy to nip female initiative in the bud. ${ }^{111}$

The ostentatious display of difference, though, covered up rather than negated profound similarities between "Guelph" and "patriotic" charities by the turn of the century. Like their diaconal colleagues, the Clementinenhaus opted for outreach programs that established a Red Cross presence in various hospitals and community nursing stations throughout Hanover. This was the right business strategy because patient numbers skyrocketed from 1,841 (in 1877) to 35,169 (in 1910). ${ }^{112}$ The peaceful transition in Hanoverian confessional nursing is evidence - in spite of persistently tough competition for clients - of a consolidating modus vivendi premised on coexistence. ${ }^{113}$ Young women learned to choose the charity that suited their own preferences best without facing moral dilemmas

\footnotetext{
${ }^{108}$ Weber-Reich, "Wir sind die Pionierinnen der Pflege," 126; Süchting-Hänger, Das "Gewissen der Nation," 44-45.

${ }^{109}$ Jahresbericht der Provinzial-Krankenpflegerinnenanstalt Clementinenhaus zu Hannover 1893 (Linden: Clementinenhaus, 1894), 7.

${ }^{110}$ Rothert, Die innere Mission, 272-75. Why the Henriettenstift operated exclusively outside German borders can only be speculated upon in the absence of conclusive evidence. See, however, Fiona Schulte, Heil und Heilung. Entwicklung und Bedeutung der medizinischen Arbeit in der Hermannsburger Mission von 1849 bis 1945 (Hermannsburg: Verlag der Missionshandlung Hermannsburg, 1998), 118-20, 164.

${ }^{111}$ Weber-Reich, "Wir sind die Pionierinnen der Pflege," 129.

${ }^{112}$ Willms-Wildermuth, Die 25-jährige Geschichte des Clementinenhauses, 44, 48. Olga von Lützerode, Bericht für das Jahr 1900, 1. Jahresbericht der Provinzial-Krankenpflegerinnen-Anstalt Clementinenhaus (Hannover: Clementinenhaus, 1911), 2, 4.

${ }^{113}$ The magistrate of Hannover, for instance, favored Clementinenhaus nurses because of their religious tolerance. When a new municipal hospital was opened in 1895, however, the Henriettenstift secured the contract because Büttner undercut the competition with cheaper wages. Weber-Reich, "Wir sind die Pionierinnen der Pflege," 108.
} 
where trade-offs became difficult to avoid. Hence, although ego-documents to back up this claim are scarce, non-Hanoverian deaconesses in the Henriettenstift presumably came to terms with the ubiquitous Guelph cult since it did not otherwise interfere with the work of the Inner Mission. ${ }^{114}$

It was in keeping with their Christian mission statement and acceptance of the altered political situation that the deaconesses and Frederica Sisters, like all other major Hanoverian charities, placed themselves at the disposal of the Prussian army when war broke out in 1914. Parts of Henriettenstift hospitals were converted for military purposes, and ninety-six convent members ended up near the front. The Frederica Association followed suit, making twenty beds available to wounded soldiers (some of whom would later plant a "war oak" in the Associationowned hospital garden as a token of their gratitude). ${ }^{115}$ The Sisters of Charity, too, detailed about 130 of their numbers for duty in military hospitals and sent another seventeen to France. ${ }^{116}$ Unsurprisingly, the Clementinenhaus's patriotic fervor could not be beaten; seventy-two of the less than 200 Red Cross sisters were sent to various theaters of war until the end of the year, not counting the nurses who stayed behind to train auxiliaries and look after crippled armed forces personnel on the "home front."117

World War I therefore marked in many ways the logical culmination of a long, but not preordained, process of charities' integration into the political culture of the Hohenzollern empire. Prussian state builders got what they wanted - a loyal pool of trained medical staff committed to shoring up the incipient welfare state and the logistics of warfare- as did the religious charity workers themselves. Like their ancestors in 1870-71, they considered war a God-given opportunity to put their altruism into action, but unlike them, the pastors who acted as the "spiritual conscience" of Lutheran charities had little inclination to question the wisdom of hypernationalism anymore. Nowhere was Christianity more highly developed than in Germany, Superintendent General Schwerdtmann explained to the celebrants of the Henriettenstift's fifty-fifth anniversary in June 1915, and his colleague, the abbot of Loccum, remarked joyfully to the members of the Frederica Association on a similar occasion two months later that all political differences had vanished. Serving and dying for the nation now meant everything. ${ }^{118}$ These utterances were commonplace in Germany throughout the first year of the war, but their surfacing in the hallowed ranks of Hanoverian

${ }^{114}$ Cf. C. Schröder, "Eine neue Heimat im Mutterhaus," 43.

${ }^{115}$ Hans Hustedt, 125 Jahre Friederikenstift Hannover 1840-1965 (Hannover: Friederikenstift, 1965), 55.

${ }^{116}$ Sterner, Kongregation der Barmherzigen Schwestern, 70. Scharf-Wrede, Für den Menschen, 35.

${ }^{117}$ Jahresbericht der Provinzial-Krankenpflegerinnen-Anstalt Clementinenhaus zu Hannover für 1914 (Hannover: Clementinenhaus, 1915), 4. Provinzial-Krankenpflegerinnenanstalt Clementinenhaus, Festschrift zum 50jährigen Bestehen des Clementinenhauses Hannover am 20. September 1925 (Hannover: Edler and Krische, 1925), 13-14.

${ }^{118}$ Hannoverscher Anzeiger, June 29, 1915, 6. Author unknown, 75jährige Jubelfeier des Friederiken-Stifts 8. August 1915 (Hannover: Friederikenstift, 1915), 1. 
Lutheran orthodoxy is telling evidence that Prusso-German power politics and the imagined Heavenly Kingdom were ultimately not so antithetical after all. ${ }^{119}$

Politics and female charity were inextricably bound together in the nineteenth century. The political storm that swept over the kingdom of Hanover in summer 1866 and left in its wake a "Greater Prussia" affected nursing motherhouses profoundly. Lutheran charity workers and, to a lesser extent, Catholic sisters felt little kinship at first with a state that so blatantly worshipped Bismarckian immorality. The Frederica Association and the Henriettenstift forged a hidden transcript of resistance enabling them to retain their emotional bond with the "martyred" Landesmutter in exile while simultaneously carving out a socially conservative niche for themselves in Hanoverian society. The contrast with the ostentatious Hohenzollern cult of their Red-Cross rivals, which married visions of imperial grandeur with humanitarian service and female entrepreneurship, highlights the diverse meanings that the monarchical icon of the Landesmutter assumed after national unification. ${ }^{120}$

Viewed from a broader vantage point, what can confessional nursing in Hanover tell us about Prusso-German state formation? The complex political context of female charity is too often still relegated to a secondary position in the scholarly literature about German post-unification nationalism, despite gender historians' extensive research on the patriotic work of the Red Cross and ancillary patriotic women's associations. Studies that examine in a holistic fashion how competing dynastic and spatial identities were reconciled in the rather broader field of bourgeois female philanthropy remain in short supply. The present article has examined the contested meaning of patriotism and the Hohenzollern government's techniques in harnessing confessional nursing for its purposes. In terms of a give-and-take, Hanoverian charities retained their individual approaches to service-whether they were Lutheran-Guelph, Catholic-universalist, or humanitarian-kleindeutsch-yet, paradoxically, their commitment to Christian altruism and simultaneous rivalry also facilitated their joint participation in the creation of a PrussoGerman "caring state" and medical infrastructure geared for war. One can consequently extend to other institutions Dieter Riesenberger's verdict about Red Cross motherhouses that the blending of patriotic and religious

\footnotetext{
${ }^{119}$ Nipperdey, Religion im Umbruch, 99. Wolfgang J. Mommsen, "Die nationalgeschichtliche Umdeutung der christlichen Botschaft im Ersten Weltkrieg," in "Gott mit uns." Nation, Religion und Gewalt im 19. und frühen 20. Jahrhundert, ed. Gerd Krumeich and Hartmut Lehmann (Göttingen: Vandenhoeck \& Ruprecht, 2000), 249-61.

${ }^{120}$ For a justified critique of Quataert's tendency to treat "most Landesmütter as interchangeable," see Nancy R. Reagin, "Recent Work on German National Identity: Regional? Imperial? Gendered? Imaginary?," Central European History 37 (2004): 283.
} 
thought patterns created "system-consolidating" (systemstabilisierend) behavioral codes. ${ }^{121}$ The increasingly smooth cooperation between female charities and the Prussian government drew further sustenance from the fact that, with the exception of the Culture War interlude, Berlin could afford to treat nonconformist political views with considerable leniency since nurses had no suffrage. This sidelining of political differences at the same time illustrates the social importance of private charity and the dependence of the state on the latter's goodwill, but that dependence also worked the other way. While charities competed among themselves, the central and provincial governments could play one against the other. How susceptible even the Henriettenstift and the Frederica Association were to such manipulation and the gravity field of ultranationalism (once they had recovered from the "harrowing" collapse of the Kaiserreich) became painfully clear under the Nazi regime. ${ }^{122}$ Put on the defensive by party functionaries, who groomed the "Brown Sisters" as their replacements, the Lutheran nurses willingly helped to implement Nationalist Socialist ideology and in the process contributed to one of the pre-World War II period's darkest chapters, namely the enforced sterilization of countless "genetically inferior" fellow citizens. ${ }^{123}$

UNIVERSITY OF BERNE

\footnotetext{
${ }^{121}$ Dieter Riesenberger, "Zur Professionalisierung und Militarisierung der Schwestern vom 'Roten Kreuz' vor dem Ersten Weltkrieg," Militärgeschichtliche Mitteilungen 53 (1994): 72. Cf. Jakob Vogel, "Samariter und Schwestern. Geschlechterbilder und -beziehungen im 'Deutschen Roten Kreuz' vor dem Ersten Weltkrieg," in Landsknechte, Soldatenfrauen und Nationalkrieger, ed. Hagemann and Pröve, 338. Regina Schulte, "The Sick Warrior's Sister: Nursing during the First World War," in Gender Relations in German History, ed. Abrams and Harvey, 121-41.

${ }^{122}$ A very revealing indication of Hanoverian charities' convergence of political views by 1918 is the fact that both the chroniclers of the Frederica Association and the Clementinenhaus referred to the end of the war as a "shock" (in German, Erschütterung and erschütternde Ereignisse, respectively). Bericht des Friederikenstifts und Frauen-Vereins für Armen- und Krankenpflege im Friederikenstift für das Jahr 1918 (Hannover: Friederikenstift, 1919) 3. Clementinenhaus, Festschrift zum 50jährigen Bestehen des Clementinenhauses, 16.

${ }^{123}$ Kreutzer and Weber-Reich, Kultur des Pflegens, 56-61; Heide-Marie Lauterer, Liebestätigkeit für die Volksgemeinschaft. Der Kaiserswerther Verband deutscher Diakonissenmutterhäuser in den ersten Jahren des NS-Regimes (Göttingen: Vandenhoeck \& Ruprecht, 1994), 117. For a more general treatment of the churches' complicated attitude toward the Nazi "Aktion T4" euthanasia program and enforced sterilizations, see Kurt Nowak, "Euthanasie" und Sterilisierung im "Dritten Reich." Die Konfrontation der evangelischen und katholischen Kirche mit dem "Gesetz zur Verhütung erbkranken Nachwuchses" und der "Euthanasie" Aktion (Göttingen: Vandenhoeck \& Ruprecht, 1978).
} 